\title{
Pre hospital indicators in assessing the quality of care for patients with acute coronary syndrome
}

\author{
Indicadores pré-hospitalares na avaliação da qualidade da \\ assistência ao paciente com síndrome coronariana aguda \\ Indicadores pre hospitalarios para la evaluación de la calidad \\ de la atención en pacientes con síndrome coronario agudo \\ Gláucia de Souza Omori Maier
Eleine Aparecida Penha Martins
Mara Solange Gomes Dellaroza $^{b}$
}

DOl: $\quad$ http://dx.doi.org/10.1590/19831447.2015.03.50869

\footnotetext{
a Hospital Universitário de Londrina (HUL). Londrina, Paraná, Brasil.

b Universidade Estadual de Londrina (UEL). Departamento de Enfermagem. Londrina, Paraná, Brasil.
}

\begin{abstract}
Objective: to assess quality indicators related to the pre-hospital time for patients with acute coronary syndrome.

Method: collection took place at a tertiary hospital in Paraná between 2012 and 2013, through interviews and a medical record review. 94 patients participated, $52.1 \%$ male, $78.7 \%$ who were over 50 years old, $46.9 \%$ studied until the fourth grade, $60.6 \%$ were diagnosed with acute myocardial infarction.

Results: the outcomes were the time between the onset of symptoms and the decision to seek help with an average of $1022 \mathrm{~min}$ \pm 343.13 , door-to-door 805min \pm 181.78 ; and reperfusion, $455 \mathrm{~min} \pm 364.8$. The choice to seek out care within 60 min occurred in patients who were having a heart attack, and longer than 60 min in those with a history of heart attack or prior catheterization.

Conclusion: We concluded that the pre-hospital indicators studied interfered with the quality of care.
\end{abstract}

Keywords: Quality indicators, health care. Acute coronary syndrome. Time-to-treatment.

\section{RESUMO}

Objetivo: avaliar os indicadores de qualidade relativos ao tempo de atendimento pré-hospitalar a pacientes com síndrome coronariana aguda.

Método: a coleta ocorreu num hospital terciário do Paraná entre 2012 e 2013, por entrevista e análise de prontuário. Participaram 94 pacientes, sendo 52,1\% homens, 78,7\% com idade superior a 50 anos, 46,9\% estudaram até a quarta série, 60,6\% com diagnóstico de infarto agudo do miocárdio.

Resultados: os desfechos foram tempo entre o início dos sintomas e decisão de procurar ajuda com média de 1022 min. \pm 343,13, tempo porta-porta de $805 \mathrm{~min} . \pm 181,78$; e reperfusão, $455 \mathrm{~min} \pm 364,8$. A procura pelo serviço em até 60 min. ocorreu em pacientes com infarto, e superior a 60 min., naqueles com história de infarto ou cateterismo prévio.

Conclusão: Conclui-se que os indicadores pré-hospitalares estudados interferiram na qualidade da assistência.

Palavras-chave: Indicadores de qualidade em assistência à saúde. Síndrome coronariana aguda. Tempo para o tratamento.

\section{RESUMEN}

Objetivo: analizar los indicadores de calidad relacionándolos con el tiempo de la atención prehospitalarios en pacientes con síndrome coronario agudo.

Método: se recolectaron en un hospital de complejidad terciaria de Paraná entre 2012 y 2013, mediante entrevista y análisis del prontuario. Participaron 94 pacientes, 52,1\% hombres, 78,7\%, mayores de 50 años; 46,9\% había estudiado hasta el cuarto grado y $60,6 \%$ diagnosticado de infarto de miocardio.

Resultados: el indicador tiempo promedio 343.13 y \pm 1022 min entre el inicio de los síntomas y la decisión de buscar ayuda. El tiempo puerta-puerta fue 181,78 \pm 805min; y la reperfusión, 364,8 \pm 455min. La búsqueda del servicio con el diagnóstico de IAM fue inferior a 60min, y superior a 60 min el histórico de IAM o un cateterismo anterior.

Conclusión: indicadores prehospitalarios interfieren en la calidad asistencial.

Palabras clave: Indicadores de calidad de la atención de salud. Síndrome coronario agudo. Tiempo de tratamiento. 


\section{DINTRODUCTION}

The guidelines on Acute Coronary Syndrome (ACS), as they relate to best practices, recently emphasized the importance of pre-hospital care for success in treating these patients and decreasing mortality ${ }^{(1-3)}$.

ACS is characterized by the rupture or erosion of an atherosclerotic plaque in the coronary arteries, causing acute thrombosis and a sudden and critical decrease in blood flow $^{(3)}$. It includes acute non ST-segment elevation myocardial infarction (NSTEMI), ST-segment elevation myocardial infarction (STEMI) and unstable angina. NSTEMI is defined by an increase in troponin, followed by a gradual decrease or increase and more rapid decrease of creatine kinase CK-MB fraction (CK-MB), with at least one of the following criteria: ischemic symptoms; evidence, through imaging exams, of a loss of myocardial viability or abnormal segmental contraction ${ }^{(2,4)}$.

STEMI is characterized by electrocardiographic abnormalities (ST- segment elevation, depression or new left bundle branch block) or development of pathological Q waves on the electrocardiogram and unstable angina characterized by chest pain that usually starts at rest ${ }^{(4)}$.

Recent studies show a decrease in mortality from AMI thanks to the advent of reperfusion therapy, the emergence of modern antithrombotic medications and secondary prevention of the disease. Still, mortality remains substantial, approximately $12 \%$ within the first six months after AMl, which is greater in high-risk patients, and explains the continued efforts to improve the quality of care and adherence to guidelines and research ${ }^{(1-3)}$.

Most quality indicators for (AMI) relate to processes and are measured during the in-hospital period, having few studies that address the pre-hospital period and structure indicators for organization of the service ${ }^{(5)}$.

The pre-hospital period is understood as the interval between the onset of ACS signs and symptoms until the time the patient is admitted to a healthcare service ${ }^{(4)}$. There are two important components: the first comprises the time for the patient's decision to seek help and the second, the time interval between the transport and care in a healthcare service ${ }^{(1-4)}$.

Among the factors involved in the decision to seek care, is the difficulty of recognizing the signs and symptoms of AMI, the severity and time-dependent treatment of the disease. Other factors are psychosocial, such as lack of family support, fear and perception of pain, in addition to the socioeconomic factors ${ }^{(6-7)}$.

But the delay in the system for seeing these patients, occurs due to the difficulty of coordination between lev- els of care, whose problem was handled by the Ministry of Health in the IAM Line of Care protocol(8).

Health services face pre-hospital difficulties when trying to perform a quick triage of patients with ACS and identify those with STEMI that are eligible for reperfusion therapy, due to the unavailability of the electrocardiograph and staff specialized in reading the exam. Coronary reperfusion is considered the treatment of choice in STEMI cases and consists of mechanical coronary artery patency through primary percutaneous coronary intervention $(\mathrm{PCl})$ with balloons and stents ${ }^{(1-4)}$.

In addition, the time for transfer to qualified hospitals with hemodynamic services and a coronary care unit increases the delay in the conduct and treatment of these patients ${ }^{(8)}$.

Since 2003, the American College of Cardiology evaluates the quality of care for AMI based on the Donabedian triad, which includes the structure, processes and results obtained during care ${ }^{(5)}$. In this study the indicators studied were: time between onset of symptoms and the decision to seek care ${ }^{(1-4)}$, time between the first medical care referred by the patient until the time that the medical record was opened at the study site - known as door-to-door, ${ }^{(1-2)}$ and reperfusion time, characterized by the time elapsed between the first medical care until the completion of primary $\mathrm{PCl}$ in patients with STEMI ${ }^{(1-2)}$.

Considering the importance of the pre-hospital period in the treatment of these patients, this study aimed to evaluate the quality indicators for the pre-hospital time for patients with ACS.

\section{METHODOLOGY}

A descriptive, longitudinal study with a quantitative approach, whose study population included patients with ACS, such as AMI, with or without ST-segment elevation and those with unstable angina, admitted to a tertiary public hospital, located in Paraná, with a 313-hosptial bed capacity and reference for high complexity in cardiology.

This service provides assistance to patients referred by state and municipal regulation centers and also through direct contact with the emergency room, where they are evaluated by the receiving system and risk classification for emergencies, proposed by the Ministry of Health ${ }^{(9)}$. The emergency department unit has 48 beds, three of which are for emergencies and the rest are in the adult, pediatric and obstetric wards.

It has a catheterization laboratory, able to perform percutaneous coronary intervention (PCI) 12 hours a day with professionals present and 12-hours a day with a rotating schedule of on-call professionals. 
The study population was comprised of patients admitted with ACS from November 2012 to March 2013. The sample was random and made up of 94 patients older than 18 , who were diagnosed with ACS, confirmed in their medical records.

The time that the medical record is opened at the hospital, completion of the first ECG and time of cardiac catheterization in the catheterization lab were extracted from the medical records. Identification data, demographic profile and history of present illness were collected through interviews with the application of a form prepared by the researcher.

The data was entered into the SPSS 20-program database. Categorical variables were analyzed with descriptive statistics, in absolute numbers and percentages; for numerical variables the means, medians and standard deviation were used. We used the chi-square test with a $5 \%$ significance level.

The study was approved by the Ethics Committee for Research Involving Human Beings, of the State University of Londrina, by CAE Opinion n. 07063312.7.0000.5231, approved in November 2012. All patients invited agreed to participate in the study.

\section{RESULTS}

The study included 94 patients diagnosed with ACS. Among them, 39.4\% were diagnosed with unstable angina, 34.0\% with AMI with ST-segment elevation, and 26.6\% with AMI without ST-segment elevation. Table 1 shows the data from the socio-demographic profile.

The results showed that most subjects were white males, over the age of 50 . Of the respondents, $74.4 \%$ had income between the minimum wage and twice the minimum wage, and $46.9 \%$ had a level of education only up to the fourth grade.

Table 2 describes the primary medical care locations of the study participants.

Most patients, $84.0 \%$, sought primary medical care in hospitals, and of these, $38.3 \%$, sought care directly at the hospital under study. Another portion sought primary healthcare services, and only 5.3\% called the mobile emergency service and received primary care on site. Among the patients admitted for transfer, $13.8 \%$ of them went through two healthcare services before being admitted at the location of the study.

Table 3 presents the pre-hospital quality indicators related to the time for care of the patients admitted.

Among the indicators related to time, the highest average obtained was the interval between the onset of symp-

toms and the patient's decision to seek help, which was 1022 minutes or $17 \mathrm{~h} 3 \mathrm{~min}$, with a coefficient of variation (CV) of 33.6\%.

As for the patient's delay time, in Table 4, patients were categorized into two groups: one consisting of those who sought help within 60 minutes from the onset of symptoms, and the other, of people who sought help after 60 minutes. We considered business hours from 8 am to $6 \mathrm{pm}$, Monday through Friday.

In $61.7 \%$ of patients, the signs and symptoms started after business hours, however, there was no association with the time for seeking healthcare services.

Table 1 - Diagnosis and socio-demographic profile of patients with Acute Coronary Syndrome, admitted to the Emergency Department $(N=94)$. Londrina-PR, 2013

\section{Variables $(n=94)$}

n $\%$

\section{Diagnosis}

Unstable angina 37

Myocardial infarction with

ST-segment elevation

Myocardial infarction without

ST-segment elevation

\section{Age}

Under 50

Over 50

\section{Gender}

Male

Female

\section{Color/Race}

$\begin{array}{lll}\text { White } & 52 & 55.3 \\ \text { Black } & 21 & 22.3 \\ \text { Mixed Race } & 21 & 22.3\end{array}$

\section{Level of education}

Never attended school

1 to 4 years

Over 4 years

\section{Family Income}

$\begin{array}{lcc}\text { Minimum wage } & 38 & 40.4 \\ \text { Twice the minimum wage } & 32 & 34 \\ \text { Three times the minimum wage } & 10 & 10.6 \\ \text { More than 3 times the minimum wage } & 12 & 12.8 \\ \text { No income } & 02 & 02.1\end{array}$

Source: Research data, 2013 
Table 2 - Site of the primary medical care of patients with Acute Coronary Syndrome admitted to the location of the study ( $\mathrm{N}=94)$. Londrina-PR, 2013

\begin{tabular}{lcc}
\multicolumn{1}{c}{ Variables } & n & \% \\
Tertiary Hospital of the study & 36 & 38.3 \\
Secondary hospitals in the city and region & 43 & 45.7 \\
Basic Health/emergency care/outpatient unit & 10 & 10.7 \\
Mobile emergency service & 5 & 5.3 \\
Total & 94 & $100 \%$ \\
\hline
\end{tabular}

Source: Research data, 2013.

Table 3 - Analysis of the Indicators related to the time for care in the Emergency Department for a patient with Acute Coronary Syndrome ( $\mathrm{N}=94)$. Londrina-PR, 2013

\begin{tabular}{lccc}
\multicolumn{1}{c}{ Variables } & Average* & Min/Max* & $\begin{array}{c}\text { Median* } \\
\text { Standard } \\
\text { deviation* }\end{array}$ \\
$\begin{array}{l}\text { Time between onset of symptoms and the } \\
\text { decision to seek help }\end{array}$ & 1022 & $0 / 21600$ & 82.5 \\
$\begin{array}{l}\text { Time between primary medical care until arrival at } \\
\text { the reference hospital (Door-to-Door) }\end{array}$ & 805 & $14 / 8415$ & 378.13 \\
$\begin{array}{l}\text { Time for care at the reference hospital } \\
\text { Total time for coronary reperfusion }\end{array}$ & 27 & $15 / 43$ & 25.0 \\
\hline
\end{tabular}

Source: Research data, 2013.

*The values are represented in minutes.

Patients diagnosed with STEMI and NSTEMI were significantly associated with looking for help within 60 minutes, with a $p$ value $=0.01$. Patients with a history of heart attack and cardiac catheterization sought help from health services later ( $>60$ minutes), with $p=0.02$ and $p=0.01$, respectively.

\section{DDISCUSSION}

AMI was the most frequent diagnosis due to fact that the place of study is a tertiary, regional, referral center for the SUS. The socio-demographic characterization meets up with other studies, ${ }^{(10-11)}$ whose age range of patients was over 50 years old, with a discreet prevalence of males that were predominantly white. It is known that chronic degenerative diseases such as hypertension, dyslipidemia and diabetes mellitus are more present in this age group and are known to be risk factors for ACS.

As for education level, half of the patients studied only attended school until fourth grade, with a significant number of people who have never attended school, and the monthly income was found to once to twice the minimum wage.
It was noted that for most of the participants with low income and education, the results reinforce the findings of a study on Brazilian social inequality, where there is an inverse relationship of cardiovascular disease (CVD), especially ischemic, with the socioeconomic status of a population ${ }^{(7)}$.

More than half of the patients received primary care from primary and secondary healthcare services. For this reason, it was necessary to transfer to tertiary hospitals, with a door-to-door time of 805 minutes, calculated using the time interval between the first medical attention or contact until arrival at a qualified hospital.

Another portion, made up of patients with a history of AMI, went directly to the tertiary hospital, and a minority called on the mobile emergency service. The situation is the opposite in developed countries, where most patients are attended by ambulances from the start of care, and referred to reference health services ${ }^{(12)}$.

However, a study in southern Brazil, showed that the average time for attending to patients using the ambulance was longer than if they sought care themselves ${ }^{(13)}$.

Besides the difficulty of access, there is still a shortage of electrocardiograph and medical staff to diagnose STEMI in 
Table 4 - Time for deciding to seek healthcare, in patients with acute coronary syndrome admitted to the Emergency Department $(N=94)$. Londrina-PR, 2013

\begin{tabular}{|c|c|c|c|}
\hline \multirow[t]{2}{*}{ Characteristics } & \multicolumn{2}{|c|}{$\begin{array}{l}\text { Time between the onset of symptoms and } \\
\text { the decision to seek help }\end{array}$} & \multirow[t]{2}{*}{$p^{*}$} \\
\hline & Up to $60 \mathrm{~min}$ & After $60 \mathrm{~min}$ & \\
\hline \multicolumn{4}{|l|}{ Onset of symptoms } \\
\hline Business hours & $17(18.1)$ & $19(20.2)$ & \multirow[t]{2}{*}{0.50} \\
\hline Outside business hours & $28(29.8)$ & $30(31.9)$ & \\
\hline \multicolumn{4}{|l|}{ Diagnosis } \\
\hline AMI with ST-segment elevation & $18(56.2)$ & $14(43.7)$ & \multirow{3}{*}{0.01} \\
\hline AMI without ST-segment elevation & $16(64.0)$ & $09(36.0)$ & \\
\hline Unstable angina & $11(29.7)$ & $26(70.2)$ & \\
\hline \multicolumn{4}{|l|}{ Gender } \\
\hline Female & $21(22.3)$ & $24(25.5)$ & \multirow[t]{2}{*}{0.40} \\
\hline Male & $24(25.5)$ & $25(26.6)$ & \\
\hline \multicolumn{4}{|l|}{ Level of education } \\
\hline Up to 4 years & $24(25.5)$ & $34(36.2)$ & \multirow[t]{2}{*}{0.08} \\
\hline Over 4 years & $21(22.3)$ & $15(15.9)$ & \\
\hline \multicolumn{4}{|l|}{ Previous history of AMI } \\
\hline Yes & $11(32.3)$ & $23(67.6)$ & \multirow[t]{2}{*}{0.02} \\
\hline No & $34(56.7)$ & $26(43.3)$ & \\
\hline \multicolumn{4}{|l|}{ Previous history of catheterization } \\
\hline Yes & $11(31.4)$ & $24(68.6)$ & \multirow[t]{2}{*}{0.01} \\
\hline No & $34(57.6)$ & $25(42.4)$ & \\
\hline
\end{tabular}

Source: Research data, 2013

the pre-hospital time, which leads to improper transfers and time beyond what is stipulated for coronary reperfusion.

The time between the onset of symptoms and the patient's decision to seek help is one of the components of pre-hospital delay ${ }^{(12)}$ and, in this study, it accounted for approximately $55 \%$ of all delays, considering that early recognition of the signs and symptoms of AMI resulted in a shorter time for seeking health services ${ }^{(12)}$.

This indicator showed significant variation, which influenced the average value of the distribution, increasing it in relation to the median value, which was 82 minutes.

There are few studies discussing the patient's delay component in the search for help. A study done in London ${ }^{(12)}$ noticed a delay, in relation to the patient, of $186 \mathrm{~min}$, with a median time of 50 minutes. Most studies on the subject cover the total time for pre-hospital delay, such as in Turkey, ${ }_{1}^{(14)}$ where the average was $181 \mathrm{~min}$ with a median time of 70 minutes; in Rio Grande do Sul, ${ }^{(13)}$ with an average of 239 min- utes and a median time of 191 minutes, and Iran, ${ }^{(15)}$ with an average of 424 minutes and median time of 120 minutes.

When comparing the results of this indicator by the median value, we conclude that the time of 82 minutes found in this study, was superior only to the time from London and Turkey ${ }^{(12,14)}$ but lower than in other studies ${ }^{(13,15)}$.

Time for care was considered from the completion of the first electrocardiogram (ECG) or the first medication. It was above that recommended by the guidelines, which indicate $10 \mathrm{~min}^{(1-4)}$ and it is associated with the electrocardiogram not be performed during triage of patients, which is performed after they receive medical attention.

The time quality indicator between the primary care until the transfer to the referral service (door-to-door) was, on average, 13 hours. Thus, many patients lose the "golden time" for coronary reperfusion, which is 12 hours after the onset of symptoms, in addition to being more susceptible to cardiac events and hospital death(16). 
Another quality indicator is reperfusion time of patients with STEMI, calculated by the interval between the onset of symptoms until completion of the primary angioplasty to open the occluded artery. In this study, this time was 455 minutes, higher than the average found in the Grace multicenter study, of 235 minutes ${ }^{(17)}$.

The ideal would be to perform the primary $\mathrm{PCl}$ with a door-to-balloon time of 120 minutes from the first medical contact, in the case of patients transferred from other services, ${ }^{(1-2)}$ or 90 minutes in patients from a qualified hospital, ${ }_{1}^{(1,4)}$ but these values also increase with the time the patient takes to make the decision, thereby increasing the time of reperfusion.

Even in the multicenter study, the time of reperfusion was twice that recommended, but in it, data proved to fall short by a number of factors. One was the patient's decision to call on or seek medical care; the other, the fact that the patient sought primary or secondary care in the first place; and, finally, patients seeking tertiary service, even with the risk classification, face overcrowding of emergency departments with a lack of beds, human and material resources and delay in treatment ${ }^{(18)}$.

AMI patients showed a time from the start of symptoms until the decision to seek help of less than 60 minutes $(p=$ 0.01 ), as well as in London ${ }^{(12)}$ and in the Grace ${ }^{(17)}$ multicenter study.

In contrast, patients with unstable angina, previous history of AMl and cardiac catheterization took more than 60 minutes to seek out healthcare. These patients also had a longer door-to-balloon time in a similar study, where previous history of AMI was predictive of pre-hospital delay ${ }^{(19)}$.

It is believed that post-discharge guidance on the risks of mortality and complications in the early months, in addition to monitoring at a specialized outpatient clinic, interfered with the decision to seek help in an ACS episode.

In this study, the socio-demographic characteristics, such as gender, marital status, educational level and the start time for symptoms had no association with the time for seeking out healthcare. In contrast, the literature shows a relationship between females and a delay in seeking help ${ }^{(20)}$ and, furthermore, a shorter time for seeking help among married people $e^{(6,12)}$.

\section{CONCLUSION}

The time indicator between onset of symptoms and decision to seek help was much better than expected, and indicates the need for educational programs about the risks and treatment time depending on the disease. The monitoring of post-AMl patients, in specialized clinics, can also improve adherence to treatment and reduce the decision time of these patients when a new episode occurs.

Indicator times between primary medical care and arrival at the referral hospital and time of care at the study site were also higher than recommended, where both indicators responsible for coronary reperfusion time were higher than 120 minutes. This delay in treatment can result in major complications, such as fatal myocardial infarction, arrhythmia and sudden death.

Even with the advent of coronary reperfusion therapy, many patients who are victims of AMI do not benefit from this treatment, due to the delay in treatment and transfer to a qualified hospital. The pre-hospital quality indicators show that the support network for patients with ACS, requires interventions in primary and pre-hospital care to ensure that eligible patients have a quick diagnosis and referral to qualified hospitals for primary $\mathrm{PCl}$.

As a contribution of this study, we know that the knowledge about the time of the patient's decision and the door-to-door time, are important healthcare indicators to be evaluated. They indicate the need for educational campaigns and dissemination of time-dependent treatment of ACS, and implementation of care and logistics protocols for the transfer of these patients.

As a limitation of the study, we considered that the factors influencing the patient's decision to seek healthcare were not surveyed, and that this is the main pre-hospital indicator responsible for the delay in service, which is also a problem that is present in developed countries.

\section{QREFERENCES}

1. O'Gara PT, Kushner FG, Ascheim DD, Casey DE Jr, Chung MK, de Lemos JA, et al. ACCF/AHA. 2013 ACCF/AHA guideline for the management of ST-elevation myocardial infarction: a report of the American College of Cardiology Foundation/American Heart Association Task Force on Practice Guidelines. J Am Coll Cardiol [Internet]. 2013 [cited 2013 Aug15];61(4):e78-140. Available from: http://www.sciencedirect.com/science/article/pii/S0735109712055623

2. Steg G, James SK, Atar D, Badano LP, Blömstrom-Lundqvist C, Borger MA, et al. ESC Guidelines for the management of acute myocardial infarction in patients presenting with ST-segment elevation. Eur Heart J [Internet]. 2012 [cited 2013 Aug 15];33(20):2569-619. Available from: http://eurheartj.oxfordjournals.org/ content/33/20/2569.long

3. Hamm CW, Bassand JP, Agewall S, Bax J, Boersma E, Bueno E, et al. ESC Guidelines for the management of acute coronary syndromes in patients presenting without persistent ST-segment elevation: the task force for the management of acute coronary syndromes(ACS) in patients presenting without persistent ST-segment elevation of the European Society of (ardiology (ESC). Eur Heart J [Internet]. 2011 [cited 2013 Aug 15]; 32(23):2999-3054. Available from: http://eurheartj.oxfordjournals.org/content/32/23/2999.full

4. Piegas LS, Feitosa G, Mattos LA, Nicolau JC, Rossi Neto JM, Timerman A, et al. IV Diretriz da Sociedade Brasileira de Cardiologia sobre tratamento do infar- 
to agudo do miocárdio com supradesnível do segmento ST. Arq Bras Cardiol. 2009;93(6 supl 2):e179-264.

5. Spertus JA, Radford MJ, Every NR, Ellerbeck EF, Peterson ED, Krumholz HM, et al. Challenges and opportunities in quantifying the quality of care for acute myocardial infarction: summary from the acute myocardial infarction working group of the American Heart Association/American College of Cardiology first scientific forum on quality of care and outcomes research in cardiovascular disease and stroke. J Am Coll Cardiol [Internet]. 2003 [cited 2013 June 15];41(9):1653-63. Available from: http://www.sciencedirect.com/science/ article/pii/S0735109703004157

6. Fournier S, Muller 0, Ludman AJ, Lauriers N, Eeckhout E. Influence of socioeconomic factors on delays, management and outcome amongst patients with acute myocardial infarction undergoing primary percutaneous coronary intervention. Swiss Med Wkly. [Internet]. 2013 [cited 2013 July 2013];143:w13817. Available from: http://www.smw.ch/content/smw-2013-13817/

7. Ishitani LH, Franco GC, Perpetuo IHOP, França E. Desigualdade social e mortalidade precoce por doenças cardiovasculares no Brasil. Rev Saúde Pública. 2006;40(4):684-91.

8. Ministério da Saúde (BR). Portaria nº 2.994, de 13 de dezembro de 2011. Aprova a linha de cuidado do infarto agudo do miocárdio e o protocolo de síndromes coronarianas agudas, cria e altera procedimentos na tabela de procedimentos, medicamentos, órteses, próteses e materiais especiais do SUS. Brasília; 2011. [cited in 2015 maio 10]. Available at: http://bvsms.saude.gov.br/bvs/saudelegis/gm/2011/prt2994_15_12_2011.html.

9. Ministério da Saúde (BR), Secretaria de Atenção Básica, Política Nacional de Humanização da Atenção e Gestão do SUS. Acolhimento com classificação de risco [Internet]. Brasília: Ministério da Saúde; 2007 [cited in 2013 jun. 19]. Available at: http://bvsms.saude.gov.br/bvs/publicacoes/acolhimento_classificaao_risc0_servico_urgencia

10. Escosteguy CC, Teixeira AB, Portela MC, Guimarães AEC, Lima SML, Ferreira VMB, et al. Implementando diretrizes clínicas na atenção ao infarto agudo do miocárdio em uma emergência pública. Arq Bras Cardiol. 2011;96(1):18-25.

11. Lemos KF, Davis R, Moraes MA, Azzolin K. Prevalência de fatores de risco para síndrome coronariana aguda em pacientes atendidos em uma emergência. Rev Gaúcha Enferm. 2010;31(1):129-35.

12. Perkins-Porras L, Whitehead DL, Strike PC, Steptoe A. Pre-hospital delay in patients with acute coronary syndrome: factors associated with patient deci- sion time and home-to-hospital delay. Eur J Cardiovasc Nurs [Internet]. 2009 [cited 2013 Aug 10]; 8(1):26-33. Available from: http://cnu.sagepub.com/content/8/1/26.full.pdf+html

13. Franco B, Rabelo ER, Goldemeyer $S$, Souza EM. Pacientes com infarto agudo do miocárdio e os fatores que interferem na procura por serviço de emergência: implicações para a educação em saúde. Rev Latino-am Enferm [Internet]. 2008 [cited in 2013 jan. 15];16(3):414-8. Available from: http://www.scielo.br/pdf/ rlae/v16n3/pt_13.pdf

14. Sari I, Açar Z, Ozer O, Erer B, Tekbas E, Uçer E, et al. Factors associated with prolonged prehospital delay in patients with acute myocardial infarction. Arch Turk Soc Cardiol [Internet]. 2008 [cited 2013 Aug 10]; 36(3):156-162. Available from: http://www.tkd.org.tr/english.asp?pg=:dergi/dergi_content\&plng=eng\&id $=1652 \&$ dosya $=160$

15. Momeni M, Salari A, Shafighnia S, Ghanbari A, Mirbolouk F. Factors influencing pre-hospital delay among patients with acute myocardial infarction in Iran. Chin Med J [Internet]. 2012 [cited 2013 Aug 10]; 25(19):3404-09. Available from: http://www.ecmj.org.cn/ch/reader/view_abstract_ext.aspx?file_ no $=201210640285660 \&$ flag $=1$

16. Masoudi FA, Bonow RO, Brindis RG, Cannon CP, DeBuhr J, Fitzgerald S, et al. ACC/ AHA 2008 statement on performance measurement and reperfusion therapy. A report of the ACC/AHA. Task Force on Performance Measures (Work Group to Address the Challenges of Performance Measurement and Reperfusion Therapy). Circulation [Internet]. 2008 [cited 2013 July 10]; 118:2649-61. Available from: http://circ.ahajournals.org/content/118/24/2649.full.pdf

17. Goldberg RJ, Spencer FA, Fox KA, Brieger D, Steg PG, Gurfinkel E, et al. Prehospital delay in patients with acute coronary syndromes (from the Global Registry of Acute Coronary Events [GRACE]). Am J Cardiol. 2009;103(5):598-603.

18. Maier GSO. Síndrome coronariana aguda: avaliação da qualidade no atendimento a pacientes admitidos em um hospital público terciário [dissertação]. Londrina: Universidade Estadual de Londrina; 2013.

19. McKinley S, Dracup K, Moser DK, Ball C, Yamasaki K, Kim CJ, et al. International comparison of factors associated with delay in presentation for AMI treatment. Eur J Cardiovasc Nurs. 2004;3(3):225-30.

20. Spencer FA, Montalescot G, Fox KAA, Goodmam SG, Granger CB, Goldberg RJ, Oliveira $G B$, et al. Delay to reperfusion in patients with acute myocardial infarction presenting to acute care hospitals: an international perspective. Eur Heart J. 2010;31(11):1328-36.

\section{Author's address:}

Gláucia de Souza Omori Maier

Rua Sebastião A. S. Callero, 200/casa 14, Chácaras Mussahiro

86041-263 Londrina - PR

E-mail: glauciaomori@yahoo.com.br
Received: 13.10.2014

Approved: 09.06.2015 